\title{
L(+) Lactic Acid Production by New Lactobacillus Rhamnosus B 103
}

\author{
Cristian J. B. de Lima1, Luciana F. Coelho ${ }^{1}$, Gervásio P. Da Silva1, Georgina L. M. Alvarez ${ }^{2}$ and J. Contiero $^{1 *}$
}

${ }^{1}$ Biological Sciences Institute, Unesp - Univ. Estadual Paulista, Campus de Rio Claro Department of Biochemistry and Microbiology, Lab. of Industrial Microbiology, Av. 24-A, 1515 Bela Vista, 13506-900, Rio Claro, SP, Brazil

2Instituto Cubano de Investigaciones de los Derivados de la Caña de Azúcar (ICIDCA), Vía Blanca 804, C.P. 11 000, Apdo, 4026, La Habana, Cuba

$\left[\begin{array}{l}\text { Abstract } \\ \mathrm{L}(+) \text { Lactic acid fermentation was studied by Lactobacillus rhamnosus sp. under the effects of } \mathrm{pH} \text { control and a low- } \\ \text { cost nutritional medium (sugarcane juice and corn steep liquor-CSL). Central composite design (CCD) was employed } \\ \text { to determine maximum lactic acid production at optimum values for process variables and a satisfactory fit model was } \\ \text { realized. Statistical analysis of the results showed that the linear and quadratic terms of two variables (sugarcane juice } \\ \text { and } \mathrm{pH} \text { ) had significant effects. The interactions between the three variables were found to contribute to the response } \\ \text { at a significant level. A second-order polynomial regression model estimated that the maximum lactic acid production } \\ \text { of } 86.36 \mathrm{~g} / \mathrm{L} \text { was obtained when the optimum values of sucrose, } \mathrm{CSL} \text { and } \mathrm{pH} \text { were } 112.65 \mathrm{~g} / \mathrm{L}, 29.88 \mathrm{~g} / \mathrm{L} \text { and } 6.2, \\ \text { respectively. Verification of the optimization showed that } \mathrm{L}(+) \text { lactic acid production was of } 85.06 \mathrm{~g} / \mathrm{L} \text {. Under these } \\ \text { conditions, } \mathrm{Y}_{\mathrm{p} / \mathrm{S}} \text { and } \mathrm{Q}_{\mathrm{p}} \text { values of } 0.85 \mathrm{~g} / \mathrm{g} \text { and } 1.77 \mathrm{~g} / \mathrm{Lh} \text {, respectively, were obtained after } 48 \mathrm{~h} \text { fermentation, with a } \\ \text { maximal productivity of } 2.2 \mathrm{~g} / \mathrm{L} \mathrm{h} \text { at } 30 \mathrm{~h} \text { of process. }\end{array}\right]$

Keywords: L(+) Lactic acid; Sugarcane; Corn steep liquor; Lactobacillus rhamnosus; Response surface methodology

\section{Introduction}

Interest in L-lactic acid production has increased recently due to its ability to serve as raw material for the manufacture of green solvents, such as ethyl lactate and poly-L-lactic acid (PLLA), which are biodegradable and environmentally friendly. PLLA is also biocompatible and can be used in implants, such as scaffolds in humans (Longacre et al., 1997). General media used for the growth of lactic acid bacteria are not economically attractive because of their expensive nutrients, such as yeast extract and peptone (Mercier et al., 1992). New low-cost media for lactic acid fermentation are needed in order to improve the economics of lactic acid production by bacteria (Nancib et al., 2001). Pure lactic acid in its L-form can be produced from submerged cultures of Lactobacillus rhamnosus with a simple and low-cost medium.

The use of alternative substrates in fermentation processes involves low-cost raw materials from agriculture. This practice reduces the cost of the culture medium and, consequently, the final cost of the product. In addition to the carbon source and other nutrients, agricultural substrates have a complex composition that may contribute toward increasing metabolite production.

Agricultural substrates may have elements in their composition capable of inhibiting the growth of the microorganism and/or preventing the synthesis of the metabolite of interest. Thus, although virtually any natural substrate can be used as substrate for microorganism culturing, a feasibility study of the viability of the substrate is a necessary step to ensure its use in scale up (Honorato et al., 2007).

Corn steep liquor (byproduct of the corn milling industry) is a low-cost nutritional medium used successfully in the production of ethanol by Zymomonas mobilis, succinic acid by Anaerobiospirillum succiniciproducens and arabinanase by Fusarium oxysporum (Kadam and Newman, 1997; Cheilas et al., 2000; Lee et al., 2000; Silveira et al., 2001). From an economical point of view, it is of interest to substitute some of the expensive components of the general lactobacillus media with corn steep liquor, which is an excellent source of nitrogen for most microorganisms, as it is high in amino acids and polypeptides, with considerable amounts of B-complex vitamins (Cardinal and Hedrick, 1948).

The biotechnological procedures used for lactic acid production are traditionally based on the bioconversion of sugar solutions by bacteria (Hofvendahl and Hahn-Hagerdal, 2000). Both chemical and biotechnological methods are available for manufacturing lactic acid, but biotechnological production offers several advantages over chemical synthesis, such as the low cost of substrates, milder temperature and low energy consumption (John et al., 2007). Lactic acid produced through biotechnological fermentation is also preferred for applications in polymer industries due to the prospects of environmental friendliness and the use of renewable sources rather than petrochemicals (John et al., 2007; Wee et al., 2006).

The purest product is obtained when a pure sugar is fermented, resulting in lower purification costs. However, this is economically unfavorable, as pure sugars are expensive and lactic acid is a relatively cheap product (Hofvendahl and Hahn-Hagerdal, 2000; Oh et al., 2005). A number of different substrates have been used for the biotechnological production of lactic acid, including glucose, sucrose, lactose, maltose, mannose, xylose and galactose.

Sugarcane occupies an important place in agriculture due to its economic and social importance. It is one of the

*Corresponding author: Jonas Contiero, Department of Biochemistry and Microbiology, São Paulo State University-UNESP, 13506 - 900 Rio Claro - SP, Tel: +55 19 35264180; Fax: +55 19 35264176; E-mail: jconti@rc.unesp.br

Received January 18, 2010; Accepted April 20, 2010; Published April 20, 2010

Citation: de Lima CJB, Coelho LF, da Silva GP, Alvarez G, Contiero J (2010) L(+) Lactic Acid Production by New Lactobacillus Rhamnosus B 103. J Microbial Biochem Technol 2: 064-069. doi:10.4172/1948-5948.1000025

Copyright: (C) 2010 de Lima CJB, et al. This is an open-access article distributed under the terms of the Creative Commons Attribution License, which permits unrestricted use, distribution, and reproduction in any medium, provided the original author and source are credited. 
most cultivated species in the world, grown in more than 80 countries. In Brazil, sugarcane cultivation is one of the oldest economic activities and covers 6.6 million hectares.

Due to its rich composition in fermentable sugars, nitrogenous substances (proteins and amino acids) and vitamins (Lima et al., 1975) as well as its low cost and high availability in Brazil, sugarcane juice may be suggested as a substrate for improving lactic acid production and reducing costs.

The response surface methodology has been successfully used to model and optimize biochemistry and biotechnology processes related to food systems (Parajo et al., 1995; Vazquez et al., 1998; Ramirez et al., 2000). This methodology could be employed to optimize lactic acid fermentation media.

The aim of the present study was to optimize the production of $\mathrm{L}(+)$ lactic acid by Lactobacillus rhamnosus, investigating the effects of $\mathrm{pH}$ control and a reduced nutritional medium composed of sugarcane juice and corn steep liquor.

\section{Materials and Methods}

\section{Materials}

Corn steep liquor was obtained from Corn Products Co. (Mogi-Guacu, Brazil) and sugarcane juice was obtained from the Santa Lucia Sugar Processing Plant (Araras-SP, Brazil).

\section{Microorganism}

Lactobacillus rhamnosus sp. B 103 was obtained from the Instituto Cubano de Investigaciones de los Derivados de la Cana de Az ú gar (ICIDCA). The strain was stored in de Man, Rogosa and Sharpe (MRS) broth with $20 \%$ (v/v) glycerol at $-10^{\circ} \mathrm{C}$.

\section{Medium and growth conditions}

The inoculum was prepared through the transference of 1 $\mathrm{mL}$ of stock culture to Erlenmeyer flasks containing $100 \mathrm{~mL}$ of growth medium (MRS). MRS growth medium composition (g/L): peptone (10.0), yeast extract (5.0), meat extract (10.0), glucose (20.0), sodium acetate (5.0), ammonium citrate (2.0), $\mathrm{K}_{2} \mathrm{HPO}_{4}$ (5.0), $\mathrm{Na}_{2} \mathrm{HPO}_{4} .2 \mathrm{H}_{2} \mathrm{O}$ (2.0), $\mathrm{MgSO}_{4} .7 \mathrm{H}_{2} \mathrm{O}(0.1)$ and MnSO4.4H2O (0.05). Incubation temperature was $37 \pm 1^{\circ} \mathrm{C}$ for 18 hours (New Brunswick, USA) at $200 \mathrm{rpm}$. Initial pH of the medium was adjusted to 6.7 .

Batch fermentations were carried out in six 1.5-L jar fermentors (Biothec, Brazil) containing 0.5 L of fermentation medium. A $10 \%(\mathrm{v} / \mathrm{v})$ seed culture was inoculated in the medium, the composition of which was varied based on the experimental designs. Agitation speed and culture temperature were controlled at $200 \mathrm{rpm}$ and $37 \pm 1^{\circ} \mathrm{C}$, respectively, for $48 \mathrm{~h}$. The $\mathrm{pH}$ was adjusted using $5 \mathrm{M} \mathrm{NaOH}$. All media were autoclaved for $15 \mathrm{~min}$ at $121^{\circ} \mathrm{C}$. Experiments were carried out in triplicate and the mean value was calculated.

\section{Analytical method}

The quantification of sucrose and lactic acid concentrations (20- $\mu \mathrm{L}$ sample, filtered under $0.2 \mu \mathrm{m})$ was determined using a high-performance liquid chromatography system (Waters Co., Milford, MA) equipped with a tunable UV detector set at $210 \mathrm{~nm}$. An Aminex HPX-87H ion-exchange column (300 mm $\times 7.8 \mathrm{~mm}$, Bio-Rad, Hercules, CA) was eluted with $0.005 \mathrm{~N}_{\text {of }} \mathrm{H}_{2} \mathrm{SO}_{4}$ as the mobile phase at a flow rate of $0.6 \mathrm{~mL} / \mathrm{min}$. Column temperature was maintained at $60^{\circ} \mathrm{C}$ and a refraction index (RI) detector was used. L(+) Lactic acid were determined by an enzyme test kit (R-biopharm AG - Roche, Darmstadt, Germany), as reported elsewhere (Yun et al., 2003). Cell growth was measured by a UV-160A spectrophotometer (Shimadzu Co., Tokyo, Japan) set at $650 \mathrm{~nm}$. Dry cell weight was determined by a calibration curve associated to optical density at $650 \mathrm{~nm}$ for dry weight $(\mathrm{g} / \mathrm{L})$. The samples obtained at different time intervals were centrifuged at $15,000 \mathrm{~g}$ for $15 \mathrm{~min}$.

\section{Response surface methods}

Central composite design (CCD) for three independent variables - each at five levels with six star points $( \pm \alpha=1.681)$ and three replicates at the center points - was used to develop a second order polynomial model, which determined the optimal values of variables for lactic acid production. Sucrose, CSL and $\mathrm{pH}$ were taken as variables for investigation. The variables of the experiments were coded according to the following equation:

$$
X_{i}=\frac{\left(X_{i}-X_{c p}\right)}{\Delta X_{i}}, \mathrm{i}=1,2, \ldots ., K
$$

in which $X i$ is the coded value of an independent variable; $X i$ is the real value of an independent variable; $X c p$ is the real value of an independent variable at the center point; and $\Delta X i$ is the step change value.

The behavior of the system was explained by the following quadratic equation:

$$
Y=B_{0}+\sum B_{i} X_{i}+\sum B_{i i} X_{i}^{2}+\sum B_{i j} X_{i} X_{j}
$$

in which $\mathrm{Y}$ is the predicted response, i.e. lactic acid concentration; $b_{0}$ is the offset term; $b_{i}$ is the linear effect; bii is the squared effect; $b_{i j}$ is the interaction effect; and $x_{i}$ is ith independent

\begin{tabular}{|c|c|c|c|c|c|c|}
\hline \multirow{2}{*}{ Independent Variables } & & \multicolumn{5}{|c|}{ Range and levels } \\
\cline { 2 - 8 } & & $-\alpha$ & -1 & 0 & +1 & $+\alpha$ \\
\hline Sucrose & $\mathrm{X}_{1}$ & 66.36 & 80 & 100 & 120 & 133.6 \\
\hline Corn steep liquor (CSL) & $\mathrm{X}_{2}$ & 13.18 & 20 & 30 & 40 & 46.82 \\
\hline $\mathrm{pH}$ & $\mathrm{X}_{3}$ & 4.3 & 5 & 6 & 7 & 7.7 \\
\hline
\end{tabular}

Table 1: Experimental range and levels of the independent variables used in the

\begin{tabular}{|c|c|c|c|c|c|}
\hline \multirow[b]{2}{*}{ Runs } & \multirow[b]{2}{*}{$X_{1}$} & \multirow[b]{2}{*}{$\mathrm{X}_{2}$} & \multirow[b]{2}{*}{$X_{3}$} & \multicolumn{2}{|c|}{ Lactic acid (g/L) } \\
\hline & & & & $\begin{array}{c}\text { Experimental } \\
\text { values }^{\mathrm{a}}\end{array}$ & Predicted values \\
\hline 1 & -1.00 & -1.00 & -1.00 & 46.500 & 49.832 \\
\hline 2 & -1.00 & -1.00 & 1.00 & 70.900 & 67.425 \\
\hline 3 & -1.00 & 1.00 & -1.00 & 42.560 & 40.955 \\
\hline 4 & -1.00 & 1.00 & 1.00 & 68.300 & 63.547 \\
\hline 5 & 1.00 & -1.00 & -1.00 & 62.000 & 63.521 \\
\hline 6 & 1.00 & -1.00 & 1.00 & 72.440 & 70.813 \\
\hline 7 & 1.00 & 1.00 & -1.00 & 61.400 & 61.643 \\
\hline 8 & 1.00 & 1.00 & 1.00 & 80.500 & 73.936 \\
\hline 9 & -1.681 & 0.00 & 0.00 & 59.010 & 61.317 \\
\hline 10 & 1.681 & 0.00 & 0.00 & 79.300 & 81.563 \\
\hline 11 & 0.00 & -1.681 & 0.00 & 77.740 & 76.330 \\
\hline 12 & 0.00 & 1.681 & 0.00 & 65.510 & 71.491 \\
\hline 13 & 0.00 & 0.00 & -1.681 & 33.910 & 30.276 \\
\hline 14 & 0.00 & 0.00 & 1.681 & 47.200 & 55.405 \\
\hline 15 & 0.00 & 0.00 & 0.00 & 84.210 & 83.689 \\
\hline 16 & 0.00 & 0.00 & 0.00 & 83.680 & 83.689 \\
\hline 17 & 0.00 & 0.00 & 0.00 & 83.960 & 83.689 \\
\hline
\end{tabular}
central composite design.

aalues indicate mean of triplicate observations

Table 2: Central composite design for optimization of three variables (each on five levels) in mathematically predicted and experimental values for the production of $\mathrm{L}(+)$ lactic acid by isolated Lactobacillus rhamnosus sp. 


\section{Journal of Microbial \& Biochemical Technology - Open Access}

variable. Using the CCD method, a total 17 experiments with various combinations of sucrose (sugarcane juice), CSL and $\mathrm{pH}$ were conducted. Table 1 displays the range and levels of the variables investigated.

\section{Statistical analysis}

The Statistic 7.0 software package (Stat Soft, USA) was used for the experimental designs and regression analysis of the experimental data. The response surface and contour plots were generated to understand the interaction of different variables. Statistical analysis of the model was performed to evaluate the analysis of variance (ANOVA). The quality of the polynomial model equation was statistically judged by the coefficient of determination $\left(R^{2}\right)$ and its statistical significance was determined by an $F$-test. The significance of the regression coefficients was tested by a $t$-test. The optimal points for the variables were obtained from Maple 9.5 program (Waterloo Maple Inc., Ontario, Canada).

\section{Experimental validation of the optimized condition}

In order to validate the optimization of the medium composition, three tests were carried out using the optimized condition in order to confirm the result from the analysis of the response surface.

\section{Results and Discussion}

The design matrix of the variables in coded units is displayed in Table 2 with the experimental results. The highest lactic acid production achieved in the verification experiment was 84.21 $\mathrm{g} / \mathrm{L}$, which was very close to the value predicted by the model (83.69 g/L), with $100 \mathrm{~g} / \mathrm{L}$ of sucrose, $30 \mathrm{~g} / \mathrm{L}$ of CSL and pH 6 (as seen in run 15).

The application of multiple regression analysis methods yielded the following regression equation (3) for the experimental data.

$$
\begin{gathered}
Y=83.689+6.019 \mathrm{X}_{1}-1.438 \mathrm{X}_{2}+7.471 \mathrm{X}_{3}-4.33 \mathrm{X}_{1}^{2}-3.457 \mathrm{X}_{2}^{2} \\
-14.442 \mathrm{X}_{3}^{2}+1.75 \mathrm{X}_{1} \mathrm{X}_{2}-2.575 \mathrm{X}_{1} \mathrm{X}_{3}+1.25 \mathrm{X}_{2} \mathrm{X}_{3}
\end{gathered}
$$

The quadratic model in Equation 3, with nine terms, contains linear terms, three quadratic terms and three factorial interactions, in which $\mathrm{Y}$ is the predicted response, i.e., lactic acid concentration and $\mathrm{X}_{1}, \mathrm{X}_{2}$ and $\mathrm{X}_{3}$ are the coded values of the test variables sucrose, CSL and $\mathrm{pH}$, respectively. Table 3 displays the Student's t-distribution and the corresponding values, along with the estimated parameters. Probability $(P)$ values were used as a tool to check the significance of each coefficient. A

\begin{tabular}{|c|c|c|c|c|}
\hline Factor & Coefficient & Standard error & Computed $t$-value & $P$-value \\
\hline Intercept & 83.689 & 3.271 & 25.587 & 0.000 \\
\hline $\mathrm{X}_{1}$ & 6.019 & 1.536 & 3.919 & 0.006 \\
\hline $\mathrm{X}_{2}$ & -1.439 & 1.536 & -0.937 & 0.380 \\
\hline $\mathrm{X}_{3}$ & 7.471 & 1.536 & 4.864 & 0.002 \\
\hline $\mathrm{X}_{1} \mathrm{X}_{2}$ & 1.750 & 2.007 & 0.872 & 0.412 \\
\hline $\mathrm{X}_{1} \mathrm{X}_{3}$ & -2.575 & 2.007 & -1.283 & 0.240 \\
\hline $\mathrm{X}_{2} \mathrm{X}_{3}$ & 1.250 & 2.007 & 0.623 & 0.553 \\
\hline $\mathrm{X}_{1}{ }^{2}$ & -4.330 & 1.691 & -2.561 & 0.037 \\
\hline $\mathrm{X}_{2}{ }^{2}$ & -3.457 & 1.691 & -2.045 & 0.080 \\
\hline $\mathrm{X}_{3}{ }^{2}$ & -14.442 & 1.691 & -8.543 & 0.000 \\
\hline
\end{tabular}

$\mathrm{X}_{1}=$ sucrose concentration; $\mathrm{X}_{2}=\mathrm{CSL}$ concentration; $\mathrm{X}_{3}=\mathrm{Ph}$

Table 3: Coefficients and $t$-values for $L(+)$ lactic acid production using a central composite design (CCD).

\begin{tabular}{|c|c|c|c|c|c|}
\hline Source & $\begin{array}{c}\text { Sum of } \\
\text { Squares }\end{array}$ & $\begin{array}{c}\text { Degrees of } \\
\text { freedom }\end{array}$ & $\begin{array}{c}\text { Mean } \\
\text { square }\end{array}$ & $F$-Value & $P>F$ \\
\hline Model & 3735.610 & 9 & 415.068 & 12.882 & 0.001 \\
\hline Residual & 225.543 & 7 & 32.220 & & \\
\hline Lack of Fit & 1548.363 & 10 & 154.836 & 2202.51 & 0.000 \\
\hline Pure error & 0.141 & 2 & 0.070 & & \\
\hline Total & 3961.153 & & & & \\
\hline
\end{tabular}

$\mathrm{R}^{2}=0.943 ;$ Adj $\mathrm{R}^{2}=0.869 ; \mathrm{R}=0.971$

Table 4: ANOVA for the second-order polynomial model.

larger magnitude of $t$-test and smaller $P$-value denote greater significance of the corresponding coefficient (Lee and Wang, 2001; Li and Lu, 2005).

The results reveal (Table 3) that the independent variables $X_{1}$ and $X_{3}$ had a strong positive linear effect on the response $(\mathrm{P}<0.05)$, as an increase in their concentration led to an increased yield. The same is observed with the squared variables $X_{1}^{2}$ and $X_{3}^{2}$; the negative signs revealed a reduction in lactic acid production when their concentration was increased in the system. Among these, insignificant terms (on the basis of $P$-values greater than 0.05$)$ are neglected. The Equation 3 model was modified to reduce the fitted model (Ya) (Eq. 4).

$$
Y a=83.689+6.019 \mathrm{X}_{1}+7.471 \mathrm{X}_{3}-4.33 \mathrm{X}_{1}^{2}-14.442 \mathrm{X}_{3}^{2}
$$

The statistical significance of Equation 4 was checked by an F-test and the analysis of variance (ANOVA) for the quadratic response surface model is summarized in Table 4.

The model $F$-value of 12.88 indicates that the model was significant. The $P$-value was also very low $(P=0.001)$, thereby indicating the significance of the model. The goodness of the model was checked by the determination coefficient $\left(R^{2}\right)$, which was calculated at 0.943 , indicating that $94.3 \%$ of the variability in the response could be explained by the model. Normally, a regression model with an $\mathrm{R}^{2}$-value greater than 0.9 is considered as having a very high correlation (Rao et al., 2006).

The value of the adjusted determination coefficient (adjusted $\mathrm{R}^{2}=0.869$ ) is reasonably high, which indicates the good significance of the model. The high $\mathrm{R}$ value $(0.971)$ demonstrates a high degree of agreement between the experimental observations and predicted values. The lack-of-fit $P$-value of 0.000 implies the lack of fit was significant to the pure error.

Three-D response surface curves were then plotted to explain the interactions of the medium components and optimum concentration of each component (sucrose, CSL and $\mathrm{pH}$ ) required for lactic acid production (Figure 1, Figure 2, Figure 3). Each figure presents the effect of two factors while the other factor was held at zero. These 3D plots and their respective contour plots provide a visual interpretation of the interaction between two factors and facilitate the determination of optimum experimental conditions.

Maximal lactic acid production was obtained with values of sucrose concentration and CSL concentration in the central point region (Figure 1). The convex response surfaces suggest that there are well-defined optimal variables. If the surfaces are rather symmetric and flat near the optimum, the optimized values may not vary widely from single variable conditions (Rao et al., 2006). Interactions between variables can be inferred from the shapes of the contour plots. Circular contour plots indicate that interactions between variables are negligible, as 


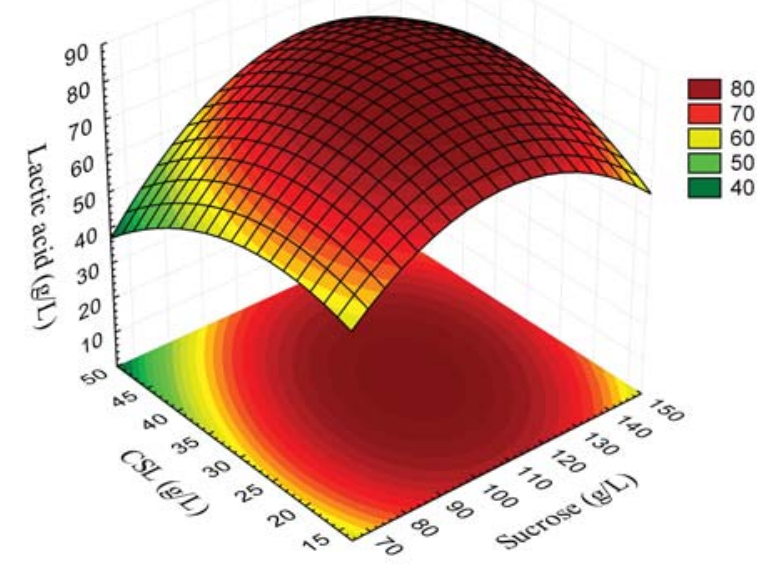

Figure 1: Response surface showing the effect of sucrose and CSL concentrations on lactic acid production.

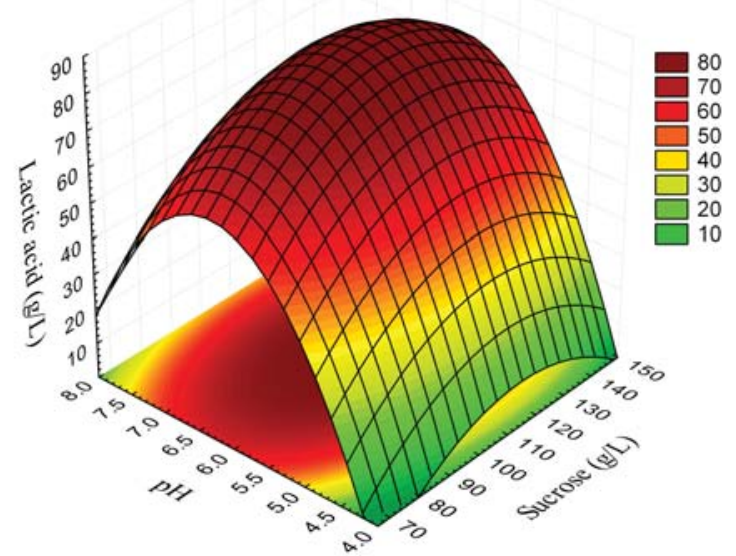

Figure 2: Response surface showing the effect of sucrose and $\mathrm{pH}$ concentrations on lactic acid production.

can be seen in Figure 1. In contrast, elliptical plots indicate interactions, as can be seen in Figure 2, Figure 3 (Muralidhar et al., 2003).

The $\mathrm{pH}$ is the dominant variable in lactic acid production. From Figure 2, Figure 3, the maximal lactic acid production occurred when $\mathrm{pH}$ was near 6 , regardless of the sucrose concentration and CSL concentration. Therefore, there were no benefits to lactic acid production with greater or lesser $\mathrm{pH}$.

The area of greater lactic acid production is located close to the central point, between 5.9 and $6.5(\mathrm{pH})$, with 90 to $130 \mathrm{~g} / \mathrm{L}$ of sucrose and 13.18 to $42 \mathrm{~g} / \mathrm{L}$ of CSL. An algorithm carried out on the Maple 9.5 program (Waterloo Maple, Inc., Canada) was used to calculate the stationary point $\left(\mathrm{P}_{0}\right)$ for the synthesis of lactic acid. The point of maximal lactic acid production was determined through canonical analysis of the adjusted model. A study was carried out to identify the nature of the stationary point (maximal point or low response or still of a saddle point). These values are displayed in Table 5. $\lambda$ values referring to sucrose, CSL and $\mathrm{pH}$ indicate that these responses have a maximal point, as they have equal and negative signs. Sucrose, CSL and pH were $112.65 \mathrm{~g} / \mathrm{L}, 29.88$ $\mathrm{g} / \mathrm{L}$ and 6.2, respectively, on the optimization point from the codified variable values $x_{1}, x_{2}$, and $x_{3}$, as shown in Table 5 . The maximal predicted value of lactic acid concentration was $86.36 \mathrm{~g} / \mathrm{L}$. To confirm the adequacy of the model for predicting maximal lactic acid production, three additional experiments in a fermentor were performed with this optimal medium composition. The mean value of lactic acid concentration was $85.06 \mathrm{~g} / \mathrm{L}$, which is in excellent agreement with the predicted value $(86.36 \mathrm{~g} / \mathrm{L})$, with a difference of just $1.53 \%$. Thus, the model was proved adequate. Figure 2 displays the lactic acid production under the optimized conditions. The final medium composition optimized with the response surface methodology was $112.65 \mathrm{~g} / \mathrm{L}$ of sucrose, $29.88 \mathrm{~g} / \mathrm{L}$ of CSL, $5.00 \mathrm{~g} / \mathrm{L}$ of sodium acetate, $2.00 \mathrm{~g} / \mathrm{L}$ of ammonium citrate, $5.00 \mathrm{~g} / \mathrm{L}$ of $\mathrm{K}_{2} \mathrm{HPO}_{4}, 2.00 \mathrm{~g} / \mathrm{L}$ of $\mathrm{Na}_{2} \mathrm{HPO}_{4} \cdot 2 \mathrm{H}_{2} \mathrm{O}, 0.10 \mathrm{~g} / \mathrm{L}$ of $\mathrm{MgSO}_{4} .7 \mathrm{H}_{2} \mathrm{O}$, $0.05 \mathrm{~g} / \mathrm{L}$ of $\mathrm{MnSO}_{4} \cdot 4 \mathrm{H}_{2} \mathrm{O}$ and initial control $\mathrm{pH}$ of 6.20 .

\section{Effect of $\mathrm{pH}$ control}

The major influence $\mathrm{pH}$ over lactic acid production in fermentation processes is due to the fact that the catalytic activity of the enzymes and metabolic activity of the microorganism depend on extracellular pH (Silva and Mancilha, 1991). According to Hofvendahl and Hahn-Hagerdal (10) optimal $\mathrm{pH}$ for lactic acid production by microorganisms varies between 5.0 and 7.0 and is dependent on the species of microorganism. Lactic acid-producing bacteria (LAB) are constantly confronted with acidified environments making acid stress part of the life cycle of LAB due to their ability to ferment sugars into lactate (Papadimitriou et al., 2006). Knowledge on the metabolic stress response caused by low $\mathrm{pH}$ in certain strains of microorganisms is of great importance for the development of many biotechnology products.

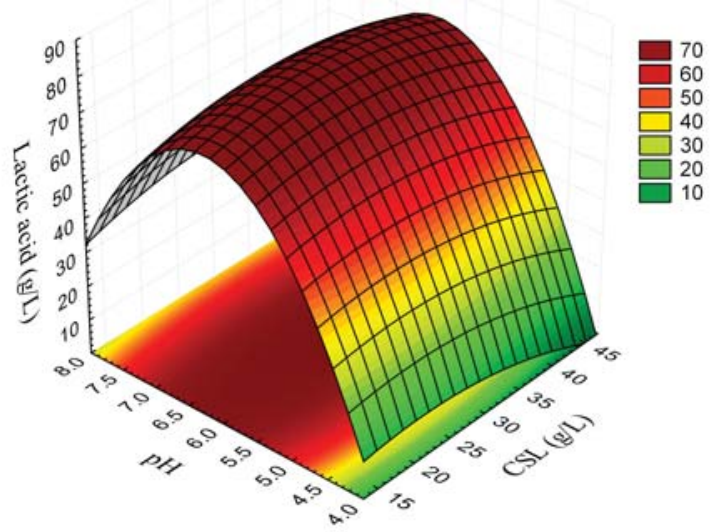

Figure 3: Response surface showing the effect of CSL and pH concentrations on lactic acid production.

\begin{tabular}{|c|c|c|c|}
\hline $\mathrm{P}_{0}$ & Lactic acid & Coordinates & Lactic acid \\
\hline$\lambda_{1}$ & -14.651 & $\mathrm{x}_{1}$ & 0.632 \\
\hline$\lambda_{2}$ & -4.664 & $\mathrm{x}_{2}$ & -0.011 \\
\hline$\lambda_{3}$ & -2.914 & $\mathrm{x}_{2}$ & 0.201 \\
\hline
\end{tabular}

Table 5: Stationary point for lactic acid production and codified values of the variables $\mathrm{x}_{1}, \mathrm{x}_{2}$, and $\mathrm{x}_{3}$ on the optimization point. 


\section{Journal of Microbial \& Biochemical Technology - Open Access}

\author{
www.omicsonline.org
}

The purpose of this experiment was to evaluate the inhibitory effect on growth and lactic acid production by L. rhamnosus exposed to conditions of stress caused by the acidification of the medium. Thus, tests were carried out using the optimal medium with and without $\mathrm{pH}$ control. The results are displayed in Figure 4.

First, it is important to note that the microorganism was able to grow and produce lactic acid in both culture media tested (with and without $\mathrm{pH}$ control). There was a similar growth pattern, reaching the stationary phase after 24 hours of fermentation. During the initial 10 hours, a similar performance was observed in fermentations with and without $\mathrm{pH}$ control. However, the consumption of the reducing sugar, lactic acid production and cell growth were influenced by the fermentation $\mathrm{pH}$ (Figure 4). With constant $\mathrm{pH}$, fermentation time was extended to 48 hours. However, when $\mathrm{pH}$ was not controlled, the microorganism metabolism was affected and consumption of the reducing sugar and lactic acid synthesis nearly ceased after 18 and 24 hours of fermentation, respectively; at this point, the $\mathrm{pH}$ of the fermentation medium was around 4.0.

According to some authors (Hofvendahl and Hahn-Hagerdal, 1997; Kashket, 1987) weak acids, e.g., lactic acid, inhibit bacterial growth because, as the external $\mathrm{pH}$ declines, the acid is protonized as soon as it is exported out of the bacteria. Uncharged, it diffuses back into the cell and dissociates due to the higher intracellular $\mathrm{pH}$. The cell then has to use ATP to pump out protons and energy is eventually depleted, causing growth to stop and the bacteria to die.

Figure 4 shows that the lactic acid production increased with

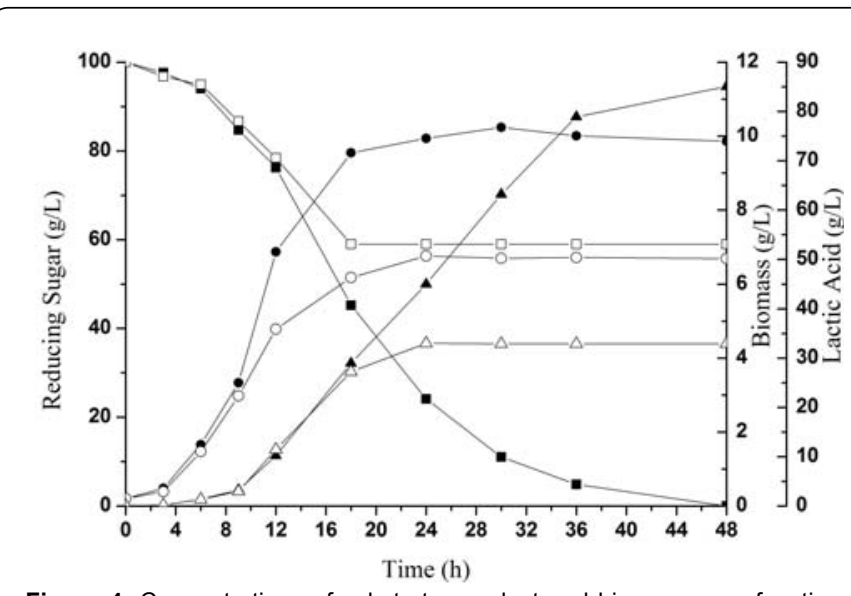

Figure 4: Concentrations of substrate, product and biomass as a function of fermentation time under optimal conditions, g/L: (ロ) reducing sugar; $(\Delta)$-lactic acid, $(\bullet)$ cell growth - with $\mathrm{pH}$ control and $(\square)$ reducing sugar; $(\Delta)$ lactic acid, (O) cell growth - without $\mathrm{pH}$ control.

\begin{tabular}{|c|c|c|}
\hline Parameters & With $\mathrm{pH}$ control & Without $\mathrm{pH}$ control \\
\hline Residual sugar $^{\mathrm{a}}(\mathrm{g} / \mathrm{L})$ & 0.00 & 59.01 \\
\hline Lactic acid $(\mathrm{g} / \mathrm{L})^{\mathrm{a}}$ & 85.06 & 32.98 \\
\hline $\mathrm{Y}_{\mathrm{P} / \mathrm{S}}{ }^{\mathrm{b}}(\mathrm{g} / \mathrm{g})$ & 0.85 & 0.80 \\
\hline $\mathrm{Y}_{\mathrm{P} / \mathrm{X}}{ }^{\mathrm{c}}(\mathrm{g} / \mathrm{g})$ & 8.31 & 4.92 \\
\hline $\mathrm{Q}_{\mathrm{P}}{ }^{\mathrm{d}}(\mathrm{g} / \mathrm{L})$ & 1.77 & 0.68 \\
\hline
\end{tabular}

${ }^{a} \mathrm{~g}$ - Reducing sugar consumed/g-initial reducing sugar $\times 100$

${ }^{\mathrm{b}} \mathrm{g}$ - Lactic acid produced/g-reducing sugar consumed;

' $g$ - Mass of product/g-cell biomass;

${ }^{\mathrm{d}} \mathrm{g}$ - Lactic acid produced/L-medium/h-fermentation time;

Table 6: Results of fermentation parameters on lactic acid production by $L$. rhamnosus in two different culture media in $\mathbf{4 8}$ hours of fermentation. the increase in biomass. However, there was slow lactic acid production in the first 9 hours, probably due to the adaptation of the microorganism to the culture medium. According to Nasr (Mussatto et al., 2008) there are inhibitory compounds in sugarcane juice such as organic acids, aldehydes, phenolic compounds and heavy metals.

After 9 hours, the lactic acid concentration (controlled $\mathrm{pH}$ ) increased rapidly, producing $85.06 \mathrm{~g} / \mathrm{L}$ in 48 hours of fermentation, with a productivity of $1.77 \mathrm{~g} / \mathrm{Lh}$ and a maximal volumetric productivity of $2.2 \mathrm{~g} / \mathrm{Lh}$ for 30 hours of process, consuming $100 \%$ of the reducing sugar in the medium. Using the medium without $\mathrm{pH}$ control, maximal lactic acid production was $32.98 \mathrm{~g} / \mathrm{L}$ in 24 hours, with this value maintained until the end of the process. Maximal volumetric productivity reached $1.37 \mathrm{~g} / \mathrm{Lh}$ in the first 24 hours and $0.68 \mathrm{~g} / \mathrm{Lh}$ at the end of 48 hours of process, consuming $41 \%$ of the reducing sugar in the medium.

Comparing the above results, there was a $158 \%$ increase in lactic acid production when the $\mathrm{pH}$ was controlled. Mussatto et al. (2008) using MRS medium supplemented with barley hydrolyzate and controlled $\mathrm{pH}$, achieved a maximal yield of $35.54 \mathrm{~g} / \mathrm{L}$ lactic acid, whereas the same medium without $\mathrm{pH}$ control yielded $13.02 \mathrm{~g} / \mathrm{L}$. This represents an increase of $170 \%$ in the production of lactic acid when $\mathrm{pH}$ was controlled.

In addition to lower lactic acid production and lower substrate consumption, cell growth was also lower in the fermentation carried out without $\mathrm{pH}$ control, reaching a maximal biomass of $6.76 \mathrm{~g} / \mathrm{L}$, whereas cell growth was $10.24 \mathrm{~g} / \mathrm{L}$ in the culture medium with $\mathrm{pH}$ control.

According to Idris and Suzana, (2006) lactic acid production depends on microbial growth - an increase in microbial growth leads to an increase in lactic acid production. During the fermentation of pineapple waste for lactic acid production by L. delbrueckii, the authors observed that the biosynthesis of lactic acid was mainly carried out during the growth phase of the microorganism. Similar results were achieved in the present work, in which good productivity values were attained in the initial $24 \mathrm{~h}$ of fermentation.

In a study carried out by Monteagudo et al., (1997) inhibitor products in the cell metabolism accumulated during microorganism growth add to the low $\mathrm{pH}$ of the medium during fermentation, which forces the cell to consume more energy in order to survive under these adverse conditions, leading to a poor performance and consequent death. The Table 6 summarizes the fermentation parameters obtained from the tests with and without $\mathrm{pH}$ control.

The large amount of residual reducing sugar in the medium without $\mathrm{pH}$ control shows that substrate consumption by Lactobacillus rhamnosus was significantly affected by $\mathrm{pH}$. When the fermentation medium was controlled, the consumption of reducing sugar was favored, resulting in the formation of lactic acid.

The rate of lactic acid production $\left(\mathrm{Y}_{\mathrm{P} / \mathrm{S}}\right)$ was considered high for the medium tested (with and without $\mathrm{pH}$ control), which suggests that the microorganism was able to convert almost all reducing sugar into lactic acid, regardless of $\mathrm{pH}$ control. The lower value was in the medium without control, 
which means that lactic acid production was affected, as substrate consumption by the organism had ceased. Lactic acid production per gram of cell $\left(\mathrm{Y}_{\mathrm{P} / \mathrm{X}}\right)$ clearly shows that $\mathrm{pH}$ control was essential for product formation by the cell.

\section{Conclusion}

Using the central composite design method and response surface analysis, it is possible to affirm that lactic acid production by $L$. rhamnosus was influenced by the carbon source (juice sugarcane) and the control of fermentation $\mathrm{pH}$. The optimization of the responses analyzed demonstrate that the best result for lactic acid production $(85.06 \mathrm{~g} / \mathrm{L})$ was obtained with 112.65 $\mathrm{g} / \mathrm{L}$ of sucrose, $29.88 \mathrm{~g} / \mathrm{L}$ of CSL and an initial controlled $\mathrm{pH}$ of 6.2. Under these conditions, $\mathrm{Y}_{\mathrm{P} / \mathrm{S}}$ and $\mathrm{Q}_{\mathrm{P}}$ values of $0.85 \mathrm{~g} / \mathrm{g}$ and $1.77 \mathrm{~g} / \mathrm{Lh}$, respectively, were obtained after $48 \mathrm{~h}$ fermentation, with a maximal productivity of $2.2 \mathrm{~g} / \mathrm{L} \mathrm{h}$ at $30 \mathrm{~h}$ of process.

\section{Acknowledgements}

The authors gratefully acknowledge the financial support provided by Fundacao de Amparo a Pesquisa de Estado do Sao Paulo (FAPESP), Brazil.

\section{References}

1. Cardinal EV, Hedrick LR (1948) Microbiological assay of corn steep liquor for amino acid content. J Biol Chem 172: 609-612.

2. Cheilas T, Stoupis T, Christakopoulos P, Katapodis P, Mamma D, et al. (2000) Hemicellulolytic activity of Fusarium oxysporum grown on sugar beet pulp. Production of extracellular arabinase. Proc Biochem 35: 557-561.

3. Hofvendahl K, Hahn-Hägerdal B (2000) Factors affecting the fermentative lactic acid production from renewable resources. Enzyme Microb Technol 26: 87-107.

4. Hofvendahl K, Hahn-Hägerdal B (1997) L-lactic acid production from whole wheat flour hydrolysate using strains of Lactobacilli and Lactococci. Enzyme Microb Technol 20: 301-307.

5. Honorato TL, Rabelo MC, Pinto GAS, Rodrigues S (2007) Production of lactic acid and dextran using cashew apple juice as a substrate. Cienc Tecnol Aliment 27: 254-258.

6. Idris A, Suzana W (2006) Effect of sodium alginate concentration, bead diameter, initial $\mathrm{pH}$ and temperature on lactic acid production from pineapple waste using immobilized Lactobacillus delbrueckii. Process Biochem 41: 11171123.

7. John RP, Nampoothiri KM, Pandey A (2007) Fermentative production of lactic acid from biomass: an overview on process developments and future perspectives. Appl Microbiol Biotechnol 74: 524-534.

8. Kadam KL, Newman MN (1997) Development of a low-cost fermentation medium for ethanol production from biomass. Appl Microbiol Biotechnol 47: 625-629.

9. Kashket ER (1987) Bioenergetics of lactic acid bacteria: cytoplasmic pH and osmotolerance. FEMS Microbial Rev 46: 233-244.

10. Lee CL, Wang WL (2001) Biological Statistics. Beijing:Science Press.

11. Lee PC, Lee WG, Lee SY, Chang HN, Chang YK (2000) Fermentative production of succinic acid from glucose and corn steep liquor by Anaerobiospirillum succiniciproducens. Biotechnol Bioproc Eng 5: 379-381.
12. Li Y, Lu J (2005) Characterization of the enzymatic degradation of arabinoxylans in grist containing wheat malt using response surface methodology. J Am Soc Brew Chem 63: 171-176.

13. Lima UA, Aquarone E, Borzani W (1975) Biotecnologia: tecnologia das fermentações. Ed Edgard Blucher 48-69.

14. Longacre AJM, Reimers JE, Gannon BE (1997) Wright, Flux Analysis of Glucose Metabolism in Rhizopus oryzae for the Purpose of Increasing Lactate Yields. Fungal Genet Biol 21: 30-39.

15. Mercier P, Yerushalmi L, Rouleau D, Dochain D (1992) Kinetics of lactic acid fermentation on glucose and corn by Lactobacillus amylophilus. J Chem Tech Biotechnol 55: 111-121.

16. Monteagudo JM, Rodríguez L, Rincón J, Fuertes J (1997) Kinetics of lactic acid fermentation by Lactobacillus delbrueckii grown on beet molasses. J Chem Tech Biotechnol 68: 271-276.

17. Muralidhar R, Gummadi SN, Dasu VV, Panda T (2003) Statistical analysis on some critical parameters affecting the formation of protoplasts from the mycelium of Penicillium griseofulvum. Biochem Eng J 16: 229-235.

18. Mussatto SI, Fernandes M, Mancilha IM, Roberto IC (2008) Effects of medium supplementation and $\mathrm{pH}$ control on lactic acid production from brewer's spent grain. Biochem Eng J 40: 437-444.

19. Nancib N, Nancib A, Boudjelal A, Benslimane C, Blanchard F, et al. (2001) The effect of supplementation by different nitrogen sources on the production of lactic acid from data juice by Lactobacillus casei subsp. rhamnosus. Bioresource Technol 78:149-153.

20. Oh H, Wee YJ, Yun JS, Han SH, Jung S, et al. (2005) Lactic acid production from agricultural resources as cheap raw material. Bioresour Technol 96: 14921498.

21. Papadimitriou K, Pratsinis H, Nebe-Von-Caron G, Kletsas D, Tsakalidou E (2006) Rapid assessment of the physiological status of Streptococcus macedonicus by flow cytometry and fluorescence probes. Int J Food Microbiology 111: 197205

22. Parajó JC, Santos V, Dominguez H, Vázquez M (1995) $\mathrm{NH} 4 \mathrm{OH}$ Based pretreatment for improving the nutritional quality of single cell protein (SCP). Appl Biochem Biotechnol 55: 133-149.

23. Ramírez JA, Santos IA, Morales OG, Morrissey M, Vázquez M (2000) Application of microbial transglutaminaseto improve mechanical properties of surimi from silver carp. Cienc Tecnol Aliment 3: 21-28.

24. Rao YK, Lu SC, Liu BL, Tzeng YM (2006) Enhanced production of an extracellular protease from Beauveria bassiana by optimization of cultivation processes. Biochem Eng J 28: 57-66.

25. Silva SS, Mancilha IM (1991) Aproveitamento de resíduos agro-industriais: ácido láctico, uma alternativa. Bol SBCTA 25: 37-40.

26. Silveira MN, Wisbeck E, Hoch I, Jonas R (2001) Production of glucose-fructose oxidoreductase and ethanol by Zimomonas mobilis ATCC29191 in medium containing corn steep liquor as a source of vitamins. Appl Microbiol Biotechnol 55: 442-445.

27. Vázquez M, Martin AM (1998) Optimization of Phaffia rhodozyma culture through response surface methodology. Biotechnol Bioeng 57: 314-320.

28. Wee YJ, Yun JS, Kim D, Ryu HW (2006) Batch and repeated batch production of $\mathrm{L}(+)$-lactic acid by Enterococcus faecalis RKY1 using wood hydrolysate and corn steep liquor. J Ind Microbiol Biotechnol 33: 431-435.

29. Yun JS, Wee YJ, Ryu HW (2003) Production of optically pure L(+)-lactic acid from various carbohydrates by batch fermentation of Enterococcus faecalis RKY1. Enzyme Microb Technol 33: 416-23. 